\title{
Silicon Supplementation Induced Influences on Yield Attributes Under Well-Watered and Water-Deficit Conditions in Different Genotypes of Rice (Oryza sativa L.)
}

\author{
Sudeshna Das, Deepti Shankhdhar and S.C. Shankhdhar*
}

Department of Plant Physiology, College of Basic Sciences \& Humanities, G. B. Pant University of Agriculture \& Technology, Pantnagar, Uttarakhand, India

*Corresponding author

\begin{tabular}{|l|l}
\hline \multicolumn{1}{l}{} & A B S T R A C T \\
\cline { 2 - 3 } \multicolumn{1}{l|}{$\begin{array}{l}\text { Keywords } \\
\text { Silicon,Drought } \\
\text { stress } \\
\text { climatic } \\
\text { conditions }\end{array}$} & $\begin{array}{l}\text { Intending to scrutinize the influence of silicon (Si) on the yield attributes of } \\
\text { rice under well-watered and water-deficit conditions, a field trial for two } \\
\text { successive years (2017 and 2018) was laid out in split- plot design with } \\
\text { four treatments viz. Control (T1), Si fertilization (T2), Si fertilization + } \\
\text { Drought stress (T3) and Drought stress (T4). The results distinctly validated } \\
\text { positive significant correlation between silicon and the yield attributes such } \\
\text { as panicle weight (flowering and maturity) and harvest index in rice under } \\
\text { well-watered conditions. Through further investigations, we could state that } \\
\text { the panicle weight at flowering and maturity, test weight and harvest index } \\
\text { which declines significantly under water deficit conditions could be } \\
\text { escalated by 49.12\%, 30\% and 14.48\% respectively through silicon } \\
\text { applications. Commercial silicon fertilization could thus prove to be a vital } \\
\text { manoeuvre in compensating the differences in yield attributes under } \\
\text { adverse climatic conditions leading to fruitful and viable crop growth. }\end{array}$ \\
\hline $\begin{array}{l}\text { Accepted: } \\
\text { Available Online: } \\
\text { 20 January 2020 }\end{array}$
\end{tabular}

\section{Introduction}

An annual plant, rice (Oryza sativa L.), is recognized to be one of the leading cereal crop as well as the staple food crop for more than half of the escalating world population (Wani et al., 2012). The two reported cultivated species of rice i.e. Oryza sativa, the Asian rice, is cultivated worldwide whereas
Oryza glaberrima, the African rice, is grown on a limited scale in West Africa (Khush, 1997), and is identified to supply more than $21 \%$ of the calorific needs of the world population, and up to $76 \%$ of the calorific intake of the population in South East Asia alone (Fitzgerald et al., 2009). The present theoretical and practical yield gap in crop plants can be attributed to a number of 
factors. Global warming along with insufficient and irregular pattern of water resources are a major intimidation to the water security in maximum parts of the world (García-Ruiz et al., 2011), resulting in drought stress which leads to a drastic reduction in crop productivity thus further endangering the food security (Abedi and Pakniyat, 2010).

Discovered to be the second most plentiful element in the earth's crust after oxygen (Iler, 1979), Silicon ( $\mathrm{Si})$ is recognized to be the skeleton of maximum number of soils (Sommer et al., 2006) and is customarily categorized into three distinct fractions: the solid phase, the liquid phase and the adsorbed phase (Matichencov and Bocharnikova, 2001; Sauer et al., 2006). The silicon form that the microorganisms and the plants are capable of uptake the uncharged form of $\mathrm{H}_{4} \mathrm{SiO}_{4} . \mathrm{H}_{4} \mathrm{SiO}_{4}$ as well as the polymerized and complexed silicic acid in soil solution is contained in the liquid silicon phase (Saccone et al., 2007; Fraysse et al., 2010).

Despite silicon being the second most abundant element on the earth's crust, it does not guarantee the idea that adequate amount of soluble silicon are accessible for plant uptake (Tubaña and Heckman, 2015). Rather than being dependent on the total Si content, the incidence of silicon ( $\mathrm{Si}$ ) deficiency in plants hugely depends on the plant available $\mathrm{Si}$ concentration in soils. It is uniquely the plant available form (PAF) of silicon i.e. silicic acid or mono silicic acid $\left[\mathrm{Si}(\mathrm{OH})_{4}\right.$ or $\mathrm{H}_{4} \mathrm{SiO}_{4}$ ] that can be absorbed by the plants.

The PAF-Si present in soil fluctuates considerably with its range stretching from 10 ppm to over 100 ppm (Liang et al., 2015). The ultimate genesis of available soil $\mathrm{Si}$ is through the process of weathering and desilication of primary silicate minerals (lithogenic $\mathrm{Si}$ ) which leads to the discharge of dissolved $\mathrm{Si}$ in the form of silicic acid (Haynes, 2014).

Two categories of Si transporters have been identified for the process of efficient uptake, translocation, and distribution of $\mathrm{Si}$ from the soil solution to the various tissues in the plant: channel-type transporters and efflux transporters (Ma and Yamaji, 2015).

Following the translocation of silicon through the transpiration stream within the plant, it precipitates close to the evaporating surfaces in cell lumina, cell walls or intercellular spaces, giving rise to amorphous $\mathrm{SiO}_{2}$ bodies, referred to as phytoliths (Jones and Handreck 1967; Epstein, 1999). These phytoliths are found deposited in both over and between leaf veins, culms and in epidermis of inflorescence and seldom in seeds (Lisztes_Szabo et al., 2014).

Silicon supplementation ameliorates several abiotic stresses which encompasses physical stress such as lodging, drought, radiation, high temperature, freezing, UV and chemical stress like salt, metal toxicity, nutrient imbalance and numerous others (Epstein, 1994). Silicon enhances drought tolerance in plants by restoring plant water balance, photosynthetic efficiency, leaf erectness as well as structure of xylem vessels under high transpiration rates due to higher temperature and moisture stress (Hattori et al., 2005).

Several experiments conducted by researchers over the years have accentuated the fact that most yield responses are the results of complex interactions whereby application of $\mathrm{Si}$ fertilizers simultaneously upsurge plant tolerance to an extensive array of abiotic and biotic stresses (Haynes, 2017). The present study was carried with the purpose of evaluating the influence of silicon on the yield attributes in rice under well-watered and water-deficit conditions. 


\section{Materials and Methods}

In order to analyze the impact of silicon on the yield attributes in rice under well-watered and water-deficit conditions, the present investigation was carried out Dr. Norman E. Borlaug Crop Research Centre and Department of Plant Physiology, College of Basic Sciences and Humanities, Govind Ballabh Pant University of Agriculture \& Technology, Pantnagar, (Uttarakhand) during the kharif season of 2017 and 2018 utilizing five rice genotypes namely PA-6129, US-312, KRH-4, IR-64 and Sahabhagidhan. The field was laid out in split-plot design with three replications of each treatment. Seedlings were raised in the nursery by wet bed method and then transplanted to the main field with a spacing of $10 \mathrm{~cm} X 20 \mathrm{~cm}$. The crop was grown under four treatments summarised as below:

T1- Control (customary package and practices as in rice were followed); T2- Silicon sprays (0.6\% ortho Silicilic acid) @ $400 \mathrm{ml}$ in 200 litres/acre land at tillering, PI, 50\% flowering and milky grain stages were given; T3Silicon + Water stress (Imposition of water stress was executed by withdrawing water from the field 14 days before flowering and withholding irrigation upto 14 days after anthesis.

Post stress duration crop was only rainfed without any surplus irrigation. Silicon was sprayed at the same rate and stages as in T2; T4- Water Stress only (Water stress was inflicted through similar procedure as in T3). At 50\% flowering and maturity, three panicles each from a different hill were plucked from each of the three replication of each treatment. They were put in envelopes and dried in oven for 24 hours at $60{ }^{\circ} \mathrm{C}$ before recording its average weight in grams. The harvest index which is the ratio of economic yield and biological yield was calculated by using the following formula:

$\mathrm{HI}(\%)=\frac{\text { Economic yield }}{\text { Biological yield }} \times 100$

The data was analyzed using two-way analysis of variance (ANOVA) by using STPR statistical software followed by test at a significance level of $\mathrm{p}<0.05$.

\section{Results and Discussion}

\section{Panicle weight}

The data in Table 1 reports the panicle weight at flowering for the rice genotypes under normal and silicon treatment. The data clearly illustrates that the enhancement in panicle weight for both the years is statistically significant for the silicon treated plants when compared to the control plants under wet conditions as well as water-deficit conditions.

In 2017, for control (T1) the maximum was observed for PA-6129 (2.57 g) whereas for silicon supplemented plants (T2) the highest panicle weight was recorded for KRH-4 (4.2 g). In case of treatments $\mathrm{T} 3$ and $\mathrm{T} 4$ the maximum panicle weight was recorded for KRH-4 (3.53 g and $2.87 \mathrm{~g}$ ) respectively whereas the minimum value was that of IR-64 recorded to be $2.43 \mathrm{~g}$ and $1.7 \mathrm{~g}$ respectively.

In 2018, for T1 the maximum panicle weight was attained by KRH-4 (2.6 g). On the other hand silicon supplemented T2 plants had the highest panicle weight recorded for $\mathrm{KRH}-4$ $(4.13 \mathrm{~g})$. In case of treatments T3 and T4 the maximum panicle weight was also attained by KRH-4 (3.53 g and $2.87 \mathrm{~g}$ respectively). The maximum percent increment in case of panicle weight at flowering for $\mathrm{T} 2$ over $\mathrm{T} 1$ for both 2017 and 2018 was noted in case of KRH-4 (72.6\% and 58.97\%) respectively. On the other hand the maximum percent increment for T3 over T4 in 2017 and 2018 was for IR-64 (43.14\% and $49.12 \%$ respectively) (Figure 1). 
The data in Table 2 reports the panicle weight at maturity for the rice genotypes under normal and silicon treatment. The data clearly illustrates that the enhancement in panicle weight at maturity for both 2017 and 2018 is statistically significant for the silicon treated plants when compared to the control plants under wet conditions as well as water-deficit conditions. In 2017, for control (T1) the maximum panicle weight was observed for PA-6129 (5.57 g). For silicon supplemented plants (T2) the highest panicle weight was recorded for PA-6129 (6.43 g). In case of treatments T3 and T4 the maximum panicle weight was recorded for PA-6129 (5.27 $\mathrm{g}$ and $4.73 \mathrm{~g}$ respectively).

In 2018, for $\mathrm{T} 1$ the maximum panicle weight was attained by PA-6129 (5.5 g) whereas the silicon supplemented T2 plants had the highest panicle weight recorded for PA-6129 $(6.83 \mathrm{~g})$. In case of treatments T3 and T4 the maximum panicle weight was attained by PA6129 (6.4 $\mathrm{g}$ and $4.93 \mathrm{~g}$ ) respectively. The maximum percent increment in case of panicle weight at maturity for T2 over T1 for both 2017 and 2018 was noted in case of PA6129 (15.57\%) and Sahabhagidhan (52.5\%) respectively. Sahabhagidhan (20\%) and PA$6129(29.73 \%)$ displayed the maximum percent increment for T3 over T4 in 2017 and 2018 respectively (Figure 2 ).

Silicon is perceived to be responsible for stomatal activity, photosynthesis and water use efficiency which subsequently leads to better vegetative and reproductive growth ultimately increasing the panicle weight (Ahmad et al., 2007; Surapornpiboon et al., 2008). Silixol treatment, when applied to rice @ $37.5 \mathrm{~kg} / \mathrm{ha}$ along with $100 \%$ recommended dose of fertilizers, recorded maximum panicle weight when compared to control (Jawahar et al., 2015).

\section{Harvest Index (HI):}

The data in Table 3 displays the harvest index for the rice genotypes under normal and silicon treatment. The data clearly specifies that the enhancement in harvest index is statistically significant for the silicon treated plants when compared to the control plants under wet conditions as well as water-deficit conditions. However, under water-deficit conditions in 2017, the HI was found to be statistically non-significant. In 2017, for control (T1) and silicon supplemented plants the maximum harvest index was observed to upsurge from $47.05 \%$ to $50.61 \%$ in case of PA-6129.

In case of treatments $\mathrm{T} 3$ and $\mathrm{T} 4$ the maximum HI value was recorded for US-312 (44.38\% and $44.14 \%$ respectively) which reveals a clear cut enhancement in case of silicon fertilized drought inflicted plants. Similarly, in 2018, for control (T1) and silicon supplemented plants the maximum harvest index was observed to upsurge from $48.48 \%$ to $53.19 \%$ in case of PA-6129.

In case of treatments $\mathrm{T} 3$ and $\mathrm{T} 4$ the maximum HI was attained by PA-6129 $(51.85 \%$ and $48.63 \%$ respectively) again implying a decrement drought stressed plants when compared to the silicon fertilized drought inflicted plants. In the current investigation the maximum percent increment in case of harvest index at for T2 over T1 for 2017 and 2018 was noted in case of Sahabhagidhan (8.04\%) and PA-6129 (9.71\%) respectively. On the other hand the maximum percent increment for T3 over T4 in 2017 and 2018 was for Sahabhagidhan (14.48\%) and IR-64 $(10.44 \%)$ respectively (Figure 3 ). Application of silicon@120 kg/ha significantly increased the yield and yield attributes in rice such as harvest. 
Table.1 Effect of foliar application of silicon on panicle weight (g) at flowering during two successive years (2017 and 2018 ) in different genotypes of rice. \pm sign indicates the standard error of mean

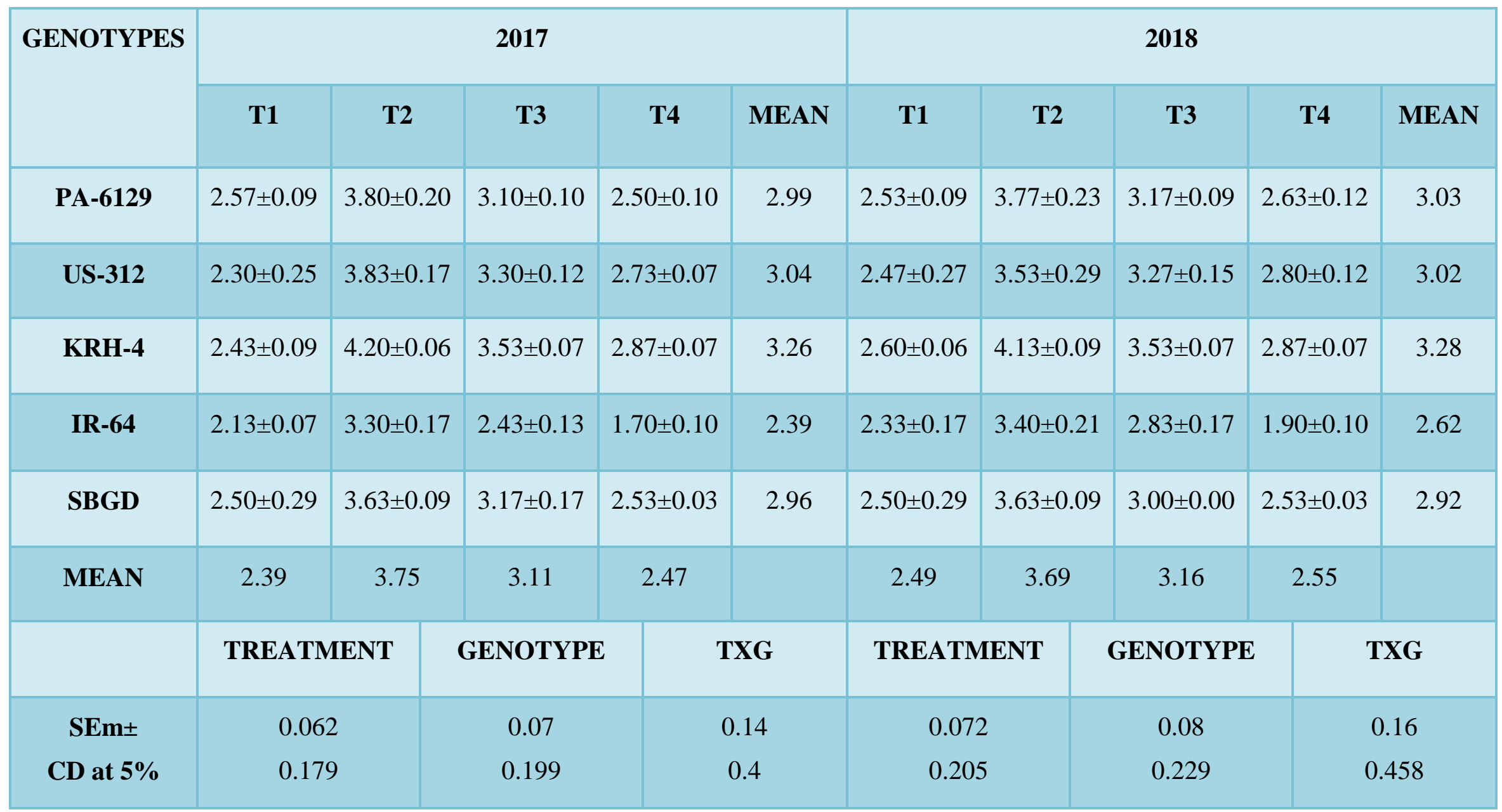


Table.2 Effect of foliar application of silicon on panicle weight (g) at maturity during two successive years (2017 and 2018$)$ in different genotypes of rice. \pm sign indicates the standard error of mean.

\begin{tabular}{|c|c|c|c|c|c|c|c|c|c|c|}
\hline \multirow[t]{2}{*}{ GENOTYPES } & \multicolumn{5}{|c|}{2017} & \multicolumn{5}{|c|}{2018} \\
\hline & $\mathbf{T 1}$ & $\mathbf{T} 2$ & T3 & T4 & MEAN & T1 & $\mathbf{T} 2$ & T3 & $\mathbf{T 4}$ & MEAN \\
\hline PA-6129 & $5.57 \pm 0.23$ & $6.43 \pm 0.20$ & $5.27 \pm 0.37$ & $4.73 \pm 0.18$ & 5.50 & $5.50 \pm 0.29$ & $6.83 \pm 0.09$ & $6.40 \pm 0.21$ & $4.93 \pm 0.18$ & 5.92 \\
\hline KRH-4 & $5.47 \pm 0.03$ & $6.23 \pm 0.12$ & $4.70 \pm 0.15$ & $4.03 \pm 0.03$ & 5.11 & $4.80 \pm 0.31$ & $5.77 \pm 0.39$ & $5.00 \pm 0.29$ & $4.90 \pm 0.10$ & 5.12 \\
\hline IR-64 & $3.80 \pm 0.49$ & $4.23 \pm 0.29$ & $3.50 \pm 0.06$ & $3.07 \pm 0.07$ & 3.65 & $3.83 \pm 0.17$ & $4.33 \pm 0.17$ & $3.77 \pm 0.23$ & $3.07 \pm 0.07$ & 3.75 \\
\hline \multirow[t]{2}{*}{ MEAN } & 5.00 & 5.55 & 4.69 & 4.03 & & 4.55 & 5.84 & 5.03 & 4.32 & \\
\hline & \multicolumn{2}{|c|}{ TREATMENT } & GENOTYPE & \multicolumn{2}{|c|}{ TXG } & \multicolumn{2}{|c|}{ TREATMENT } & GENOTYPE & \multicolumn{2}{|c|}{ TXG } \\
\hline SEm \pm & \multicolumn{2}{|c|}{0.139} & 0.155 & \multicolumn{2}{|c|}{0.311} & \multicolumn{2}{|c|}{0.142} & 0.158 & \multicolumn{2}{|c|}{0.317} \\
\hline CD at $5 \%$ & \multicolumn{2}{|c|}{0.398} & 0.445 & \multicolumn{2}{|c|}{0.89} & \multicolumn{2}{|c|}{0.405} & 0.453 & \multicolumn{2}{|c|}{0.906} \\
\hline
\end{tabular}




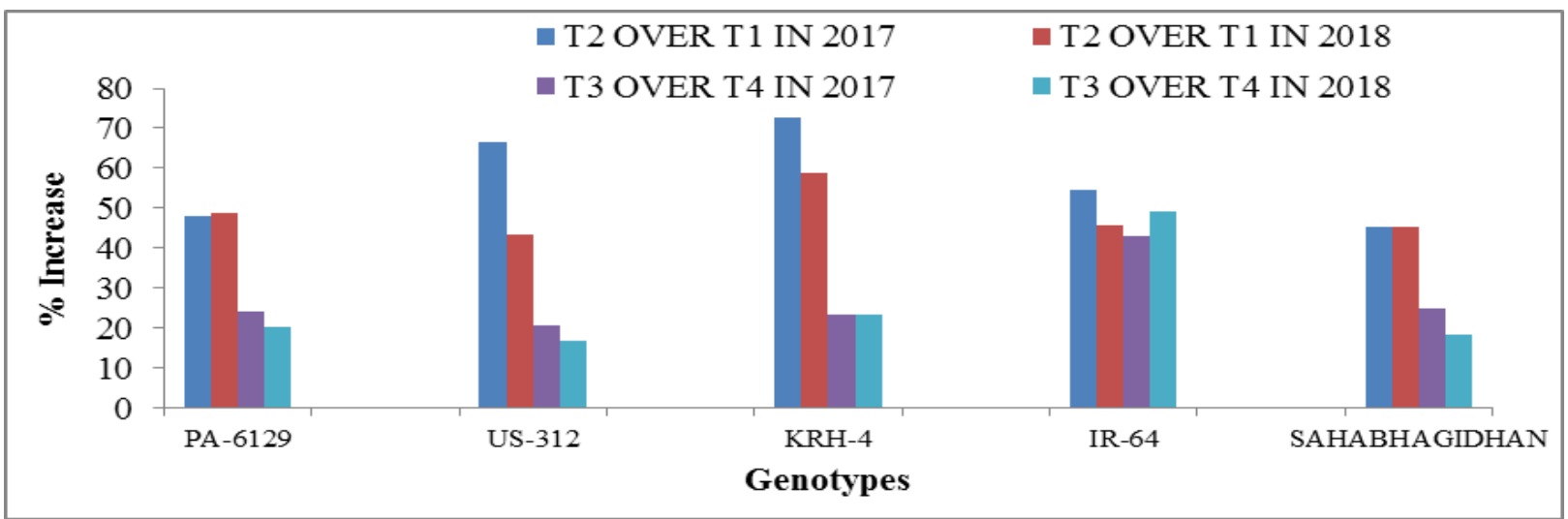

Figure.1 Graphical representation illustrating the comparative effect of foliar application of silicon on panicle weight at flowering during two successive years (2017 and 2018) in different genotypes of rice.

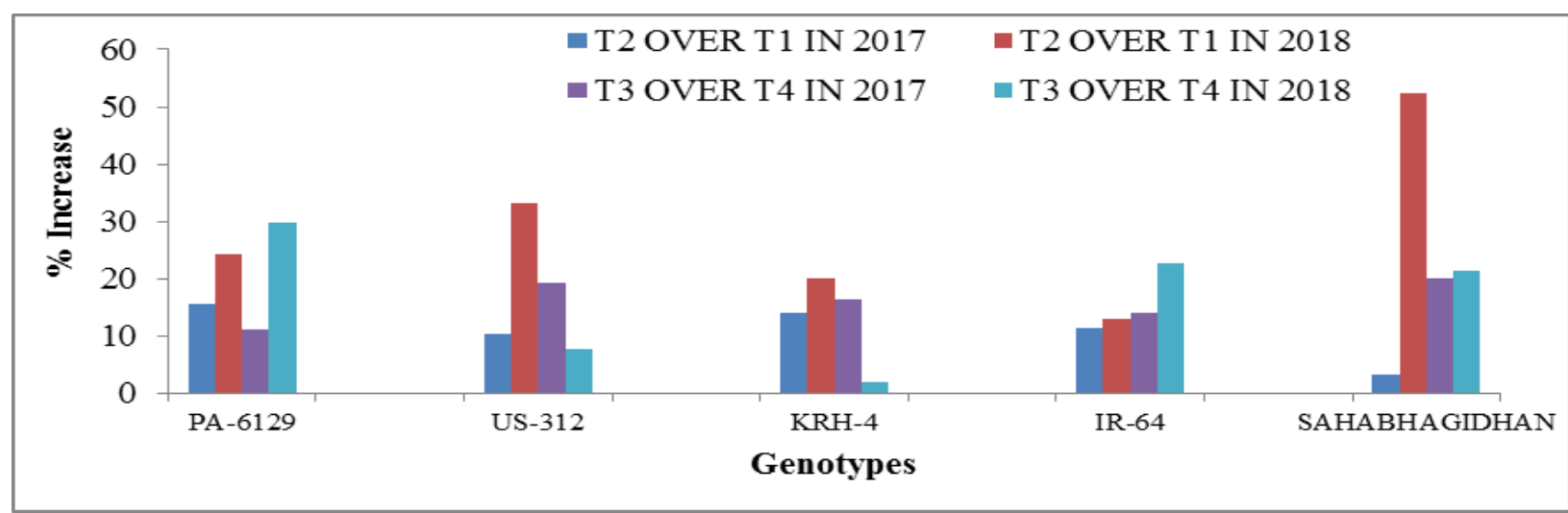

Figure.2 Illustrative diagrammatic representation depicting the comparative effect of foliar application of silicon on panicle weight at maturity during two successive years (2017 and 2018) in different genotypes of rice.

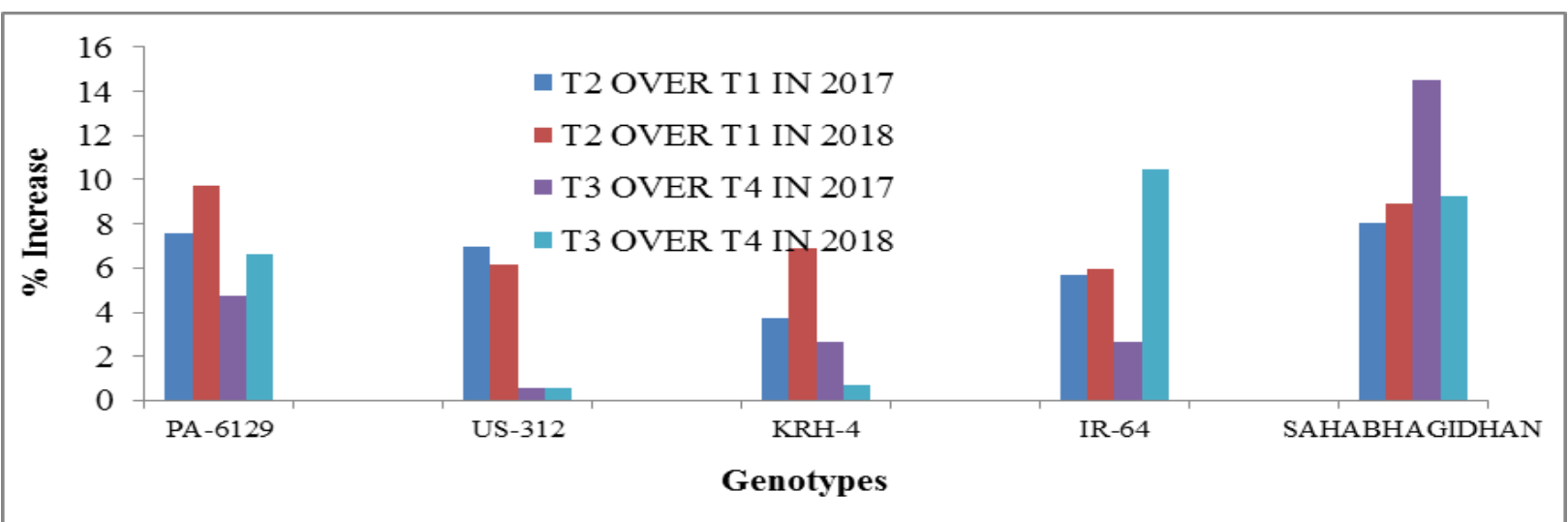

Figure.3 Symbolic representation of the comparative effect of foliar application of silicon on harvest index (\%) during two successive years (2017 and 2018) in different genotypes of rice. 
Table.3 Effect of foliar application of silicon on harvest index (\%) during two successive years (2017 and 2018) in different genotypes of rice. \pm sign indicates the standard error of mean.

\begin{tabular}{|c|c|c|c|c|c|c|c|c|c|c|}
\hline \multirow[t]{2}{*}{ GENOTYPES } & \multicolumn{5}{|c|}{2017} & \multicolumn{5}{|c|}{2018} \\
\hline & T1 & $\mathbf{T} 2$ & T3 & $\mathbf{T 4}$ & MEAN & T1 & $\mathbf{T} 2$ & T3 & $\mathbf{T 4}$ & MEAN \\
\hline PA-6129 & $47.05 \pm 0.53$ & $50.61 \pm 1.59$ & $42.25 \pm 4.84$ & $40.35 \pm 1.58$ & 45.07 & $48.48 \pm 0.28$ & $53.19 \pm 1.96$ & $51.85 \pm 3.40$ & $48.63 \pm 0.17$ & 50.54 \\
\hline US-312 & $42.29 \pm 1.69$ & $45.24 \pm 2.38$ & $44.38 \pm 1.29$ & $44.14 \pm 3.25$ & 44.01 & $41.65 \pm 0.49$ & $44.21 \pm 1.65$ & $43.45 \pm 1.53$ & $43.20 \pm 2.67$ & 43.13 \\
\hline KRH-4 & $36.85 \pm 0.85$ & $38.22 \pm 1.35$ & $40.42 \pm 0.42$ & $39.37 \pm 2.55$ & 38.72 & $40.16 \pm 1.05$ & $42.92 \pm 0.49$ & $39.87 \pm 0.36$ & $39.59 \pm 2.59$ & 40.63 \\
\hline IR-64 & $35.00 \pm 0.19$ & $36.98 \pm 1.59$ & $36.54 \pm 3.45$ & $35.59 \pm 1.44$ & 36.03 & $39.41 \pm 1.16$ & $41.75 \pm 1.49$ & $37.70 \pm 0.81$ & $34.14 \pm 0.48$ & 38.25 \\
\hline SBGD & $46.91 \pm 0.76$ & $50.68 \pm 1.52$ & $45.61 \pm 0.48$ & $39.84 \pm 2.98$ & 45.76 & $48.65 \pm 0.70$ & $52.97 \pm 0.64$ & $51.17 \pm 1.74$ & $46.82 \pm 1.16$ & 49.90 \\
\hline \multirow[t]{2}{*}{ MEAN } & 41.62 & 44.35 & 41.84 & 39.86 & & 43.67 & 47.01 & 44.81 & 42.47 & \\
\hline & \multicolumn{2}{|c|}{ TREATMENT } & GENOTYPE & \multicolumn{2}{|c|}{ TXG } & \multicolumn{2}{|c|}{ TREATMENT } & GENOTYPE & \multicolumn{2}{|c|}{ TXG } \\
\hline SEm \pm & \multicolumn{2}{|c|}{0.926} & 1.035 & & .07 & 0.656 & & 0.734 & & 468 \\
\hline CD at $5 \%$ & 2.651 & & 2.964 & & 928 & 1.879 & & 2.101 & & 202 \\
\hline
\end{tabular}


With an increased awareness among researchers and cultivators with regard to $\mathrm{Si}$ and its potential in agriculture, it is probable that the decades overlooked element will be conceded as a worthy means of sustainably managing crop yield attributes and different other crop traits under adverse climatic conditions. The existing trial carried out with the aim of assessing the effect of silicon on the yield attributes in rice under well-watered and water-deficit conditions have sketched out a positive and beneficial image of silicon. It can be effectively used in crop plants to increase its economic output under adverse conditions such as water-deficiency.

\section{Acknowledgement}

The authors are thankful to the All India Coordinated Rice Improvement Programme of ICAR and Indian Institute of Rice Research, Hyderabad for providing the essential facilities and financial support required during the all-inclusive duration of the present investigation.

\section{References}

Abedi, T. and Pakniyat, H. 2010. Antioxidant enzymes changes in response to drought stress in ten cultivars of oilseed rape (Brassica napus L.). Czech J. Genet. Plant Breed., 46(1): 27-34.

Ahmad, F., Rahmatullah, Aziz, T., Maqsood, M.A., Tahir, M.A. and Kanwal, S. 2007. Effect of silicon application on wheat (Triticum aestivum L.) growth under water deficiency stress. Emir. J. Food Agric., 19: 01-07.

Cuong, T.X., Ullah, H., Datta, A. and Hanh, T.C. 2017. Effects of silicon-based fertilizer on growth, yield and nutrient uptake of rice in tropical zone of Vietnam. Rice Sci., 24(5): 283-290.

Detmann, K.C., Araújo, W.L., Martins, S.C., Sanglard, L.M., Reis, J.V., Detmann, E.,
Rodrigues, F.Á., Nunes- Nesi, A., Fernie, A.R. and DaMatta, F.M. 2012. Silicon nutrition increases grain yield, which, in turn, exerts a feed- forward stimulation of photosynthetic rates via enhanced mesophyll conductance and alters primary metabolism in rice. New Phytol., 196(3): 752-762.

Epstein, E. 1994. The anomaly of silicon in plant biology. Proc. Natl. Acad. Sci., USA. 91: 11-17

Epstein, E. 1999. Silicon. Annu. Rev. Plant Physiol. Plant Mol. Bio., 150(1): 641664.

Fitzgerald, M.A., McCouch, S.R. and Hall, R.D. 2009. Not just a grain of rice: the quest for quality. Trends Plant Sci., 14(3): 133-139.

Fraysse, F., Pokrovsky, O.S. and Meunier, J.D. 2010. Experimental study of terrestrial plant litter interaction with aqueous solutions. Geochim. Cosmochim. Ac., 74(1): 70-84.

García-Ruiz, J.M., López-Moreno, J.I., Vicente-Serrano, S.M., LasantaMartínez, T. and Beguería, S. 2011. Mediterranean water resources in a global change scenario. Earth Sci. Rev., 105(3-4): 121-139.

Hattori, T., Inanaga, S., Araki, H., An, P., Mortia, S., Luxova, M. and Lux, A. 2005. Application of silicon enhanced drought tolerance in Sorghum bicolor. Physio. Plantarum, 123(4): 459-466

Haynes, R.J. 2014. A contemporary overview of silicon availability in agricultural soils. J. Plant Nutr. Soil Sci., 177(6): 831-844.

Haynes, R.J. 2017. The nature of biogenic Si and its potential role in Si supply in agricultural soils. Agric. Ecosyst. Environ., 245: 100-111.

Iler, P.K. 1979. The Chemistry of Silica. Wiley and Sons, New York.

Jawahar, S. and Vaiyapuri, V. 2010. Effect of sulphur and silicon fertilization on 
growth and yield of rice. Int. J. Curr. Res., 9: 36-38.

Jawahar, S., Vijayakumar, D., Bommera, R., Jain, N. and Jeevanandham. 2015. Effect of Silixol granules on growth and yield of rice. Int. J. Curr. Res. Aca. Rev., 3(12): 168-174.

Jones, L.H.P. and Handreck, K.A. 1967. Silica in soils, plants, and animals. In: Advances in agronomy. Academic Press, pp: 107-149.

Khush, G.S. 1997. Origin, dispersal, cultivation and variation of rice. Plant Mol. Biol., 35(1-2): 25-34.

Liang, Y., Nikolic, M., Bélanger, R., Gong, H. and Song, A. 2015. Silicon biogeochemistry and bioavailability in soil. In: Silicon in Agriculture. Springer, pp: 45-68.

Lisztes_Szabo, Z.S.U.Z.S.A., Kovács, S. and Petö, Á. 2014. Phytolith analysis of Poa pratensis (Poaceae) leaves. Turk. J. Bot., 38(5): 851-863.

Ma, J.F. and Yamaji, N. 2015. A cooperative system of silicon transport in plants. Trends Plant Sci., 20(7): 435-442.

Matichencov, V.V. and Bocharnikova, E.A. 2001. The relationship between silicon and soil physical and chemical properties. In: Datnoff, L.E., Snyder, G.H., Korndörfer, G.H. (eds) Silicon in Agriculture. Elsevier, pp: 209-219.

Pati, S., Pal, B., Badole, S., Hazra, G.C. and Mandal, B. 2016. Effect of silicon fertilization on growth, yield, and nutrient uptake of rice. Commun. Soil Sci. Plant Anal., 47(3): 284-290.

Saccone, L., Conley, D.J., Koning, E., Sauer, D., Sommer, M., Kaczorek, D., Blecker, S.W. and Kelly, E.F. 2007. Assessing the extraction and quantification of amorphous silica in soils of forest and grassland ecosystems. Eur. J. Soil Sci., 58(6): 1446-1459.

Sauer, D., Saccone, L., Conley, D.J., Herrmann, L. and Sommer, M. 2006. Review of methodologies for extracting plant-available and amorphous $\mathrm{Si}$ from soils and aquatic sediments. Biogeochemistry, 80(1): 89-108.

Sommer, M., Kaczorek, D., Kuzyakov, Y., and Breuer, J. 2006. Silicon pools and fluxes in soils and landscapes - a review. J. Plant Nutr. Soil Sci., 169(3): 310-329.

Suraporniboon, P., Julsrjgival, S., Senthong, C. and Karladee, D. 2008. Genetics of silicon content in upland rice under drought condition. SABRAO J. Breed. Genet., 40(1): 27-35.

Tubaña, B.S. and Heckman, J.R. 2015. Silicon in soils and plants. In: Silicon and Plant Diseases. Springer, pp: 7-51.

Wani, A.A., Singh, P., Shah, M.A., Weisz, U.S., Gul, K. and Wani, I.A. 2012. Rice starch diversity: effects on structural, morphological, thermal, and physicochemical properties - A review. Compr. Rev. Food Sci. Food Saf., 11(5): 417-436.

\section{How to cite this article:}

Sudeshna Das, Deepti Shankhdhar and Shankhdhar. S.C. 2020. Silicon Supplementation Induced Influences on Yield Attributes Under Well-Watered and Water-Deficit Conditions in Different Genotypes of Rice (Oryza sativa L.). Int.J.Curr.Microbiol.App.Sci. 9(01): 2289-2298 doi: https://doi.org/10.20546/ijcmas.2020.901.260 